\title{
Vegetation trends in a restored coastal wetland at Prisoners Harbor, Santa Cruz Island, Channel Islands National Park
}

\author{
Paula J. Power ${ }^{1}{ }^{*}$, Marie Denn ${ }^{2}$, Joel Wagner $^{3}$, and Mike Martin ${ }^{3}$ \\ ${ }^{1}$ Channel Islands National Park, Ventura, CA \\ ${ }_{2}$ National Park Service, Point Reyes National Seashore, Inverness, CA \\ ${ }^{3}$ National Park Service, Water Resources Division
}

\begin{abstract}
Prisoners Harbor on Santa Cruz Island, California, formerly supported a 5-ha wetland and riparian system, the largest on the California Channel Islands. During the late 1800s ranchers filled in about half of the wetland area in order to support ranching activities. They also rerouted the stream channel to the canyon edge and built an earthen berm along its west bank, which disconnected the stream from its floodplain. The National Park Service developed a wetland and riparian restoration design for Prisoners Harbor based on topographic and hydrologic analyses and on vegetation community depth-to-water-table relationships developed from neighboring reference wetlands. In 2011 Channel Islands National Park and The Nature Conservancy restored 1.25 ha of coastal wetlands by removing artificial fill and the earthen berm. Postproject vegetation monitoring during 2012 to 2016 showed increased abundance of 3 of the 8 herbaceous planted wetland species and declines in target invasive species. Severe drought conditions during this window likely influenced vegetation abundance. Postrestoration hydrologic monitoring showed that the restored marsh met the federal wetland hydrology standard only twice: once in late 2011 before the drought began and then again in January-September 2017. An exceptionally large swell and high tide during winter 2015/16 resulted in saltwater flooding of the site; salinity returned to more typical values only slowly after this event. Expansion of wetland species, even during a historic drought and atypical seawater intrusion, suggests that this evidence-based approach to restoration design will result in functional coastal wetland habitat as more typical precipitation levels return. However, we emphasize the need for aggressive control of nonnative plants until native plant cover is well established.
\end{abstract}

Resúmen.-El puerto Prisioneros en la Isla Santa Cruz, California, mantenía un sistema de cinco hectáreas de humedales y riberas, el más grande de las Islas del Canal de California. A fines del siglo XIX, los ganaderos cubrieron aproximadamente la mitad del área de los pantanos para apoyar las actividades ganaderas. También redirigieron la corriente del canal hacia el borde del cañón y construyeron una berma a lo largo de la ribera occidental, que desconectó la corriente de su llanura de inundación. El Servicio de Parques Nacionales desarrolló un diseño de restauración de riberas y humedales en el puerto Prisioneros, basado en análisis topográficos e hidrológicos y en la relación entre la comunidad vegetal y la profundidad del nivel freático, desarrolladas a partir de humedales de referencia vecinos. En 2011, el Parque Nacional de las Islas del Canal y la Conservación de la Naturaleza restauraron 1.25 ha de humedales costeros eliminando el relleno artificial y las bermas. El monitoreo de la vegetación posterior al proyecto durante los años 2012 al 2016 , mostró un incremento en la abundancia de tres de las ocho especies plantadas en los humedales y disminución de las especies invasoras. Las severas condiciones de sequía durante esta ventana de tiempo, probable influyeron en la abundancia vegetal. El monitoreo hidrológico posterior a la restauración, mostró que el humedal restaurado cumplió con el norma federal de hidrología de humedales sólo dos veces: a fines del año 2011, antes de que comenzara la sequía y, posteriormente, de enero a septiembre de 2017. Un oleaje excepcionalmente grande y marea alta durante el invierno de los años 2015/16, provocaron inundaciones de agua salada en la zona. La salinidad regresó lentamente a sus valores típicos luego de este suceso. La expansión de las especies de humedales, incluso durante una sequía histórica y la atípica intrusión de agua de mar, sugiere que este enfoque basado en evidencia para el diseño de restauración, dará como resultado un hábitat funcional de humedales costeros a medida que se restauren los niveles típicos de precipitación. Sin embargo, enfatizamos la necesidad de un control enérgico de las plantas no nativas hasta que la cobertura de las plantas nativas se restablezca.

Prisoners Harbor on Santa Cruz Island, California, used to support a 5-ha coastal wetland and riparian system, the largest on the California Channel Islands. Native people occupied the site for 3000 years, until the 1830s (Glassow 1980, Schoenherr et al. 1999, Arnold 2001). During the late 1800s ranchers filled in about half of the wetland area in order to support

*Corresponding author: paula_power@nps.gov 


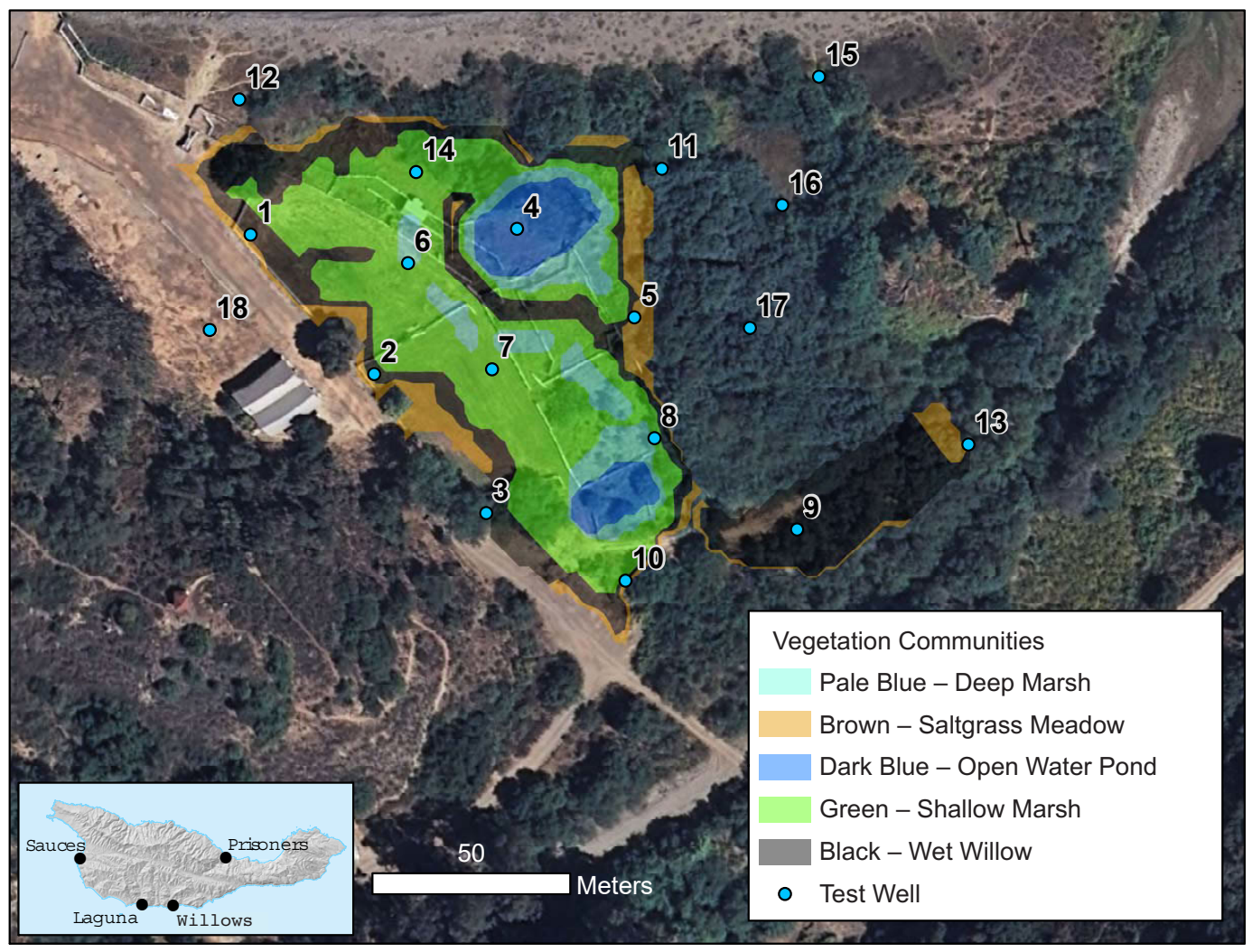

Fig. 1. Prisoners Harbor wetland restoration design plan. Data from 15 observation wells in the filled wetland area (wells 1-14, 18) and 3 wells in the adjacent reference wetland area (wells 15-17) formed the basis of the design. Inset shows the location of the restoration site on the north side of Santa Cruz Island.

livestock corrals and other ranching facilities. The ranchers also shifted the stream channel to the eastern edge of the site and built an earthen berm between the relocated stream and the ranching facilities to protect against flooding.

In 2004 Channel Islands National Park and National Park Service (NPS) Water Resources Division staff began collecting quantitative information to inform wetland restoration at Prisoners Harbor. The project's key goals were to restore predisturbance wetland and floodplain conditions at the site and, in doing so, improve habitat for native species, such as the endemic Island Scrub Jay (Aphelocoma insularis), Channel Islands fox (Urocyon littoralis), and harvest mouse (Reithrodontomys sp.), and for migratory passerine birds and waterfowl.

To inform the restoration design, the NPS project team installed 15 groundwater monitoring wells in the filled areas and a set of 3 wells through an adjacent, relatively undisturbed reference wetland area (Fig. 1). NPS staff moni- tored the wells for several years to develop a thorough understanding of site hydrology. NPS staff also completed a topographic survey and studied wetland plant communities in the reference area and at the mouths of Sauces, Laguna, and Willows Canyons on the island to develop a palette of wetland plant species and associated habitat zones. The project team based the restoration design on hydrologic analyses for the disturbed area and on a vegetation community depth-to-water-table model developed from the adjacent reference wetlands (Power et al. 2014). Using Surfer ${ }^{\circledR}$ software, the team developed the final design by first creating a mean November 2005-to-November 2006 water table contour surface for the disturbed area. The team then added or subtracted elevations according to the reference area vegetation community depth-towater-table model to create 4 targeted wetland community types for the restoration. These are saltgrass meadow ( $12 \%$ of the site), wet willow (18\%), shallow marsh (46\%), and deep marsh 
(9\%). The other $15 \%$ of the site consists of open water ponds. The project team then developed detailed grading and planting specifications to guide implementation.

In September 2011 contractors excavated over $7500 \mathrm{~m}^{3}$ (approximately 10,000 cubic yards) of fill from the former wetland area, in accordance with the restoration design, and then topographically reconnected the stream channel to the floodplain by removing the earthen berm. Later that fall NPS staff and partners planted and seeded the site with native wetland species. The project team produced a detailed account of the excavation and planting designs (including container sizes, seed and propagule sources, planting densities and zones by species, and site maintenance methods) in Power et al. 2014.

\section{METHODS}

NPS staff and partners monitored native and nonnative plants within the restoration site from 2012 to 2016 . The goals of monitoring are to (1) provide an early warning of negative trends at the site to inform postproject management and (2) provide a quantitative 5-year postproject assessment of revegetation success.

In 2012, 2013, 2015, and 2016 observers monitored the following native species that had been planted at the site:

Baccharis douglasii
Distichlis spicata
Juncus mexicanus
Juncus patens
Juncus xiphioides
Schoenoplectus californicus
Schoenoplectus maritimus
Schoenoplectus pungens

To better inform postproject management of the site, the NPS included nonnative invasive Bermuda grass (Cynodon dactylon) in the monitoring protocol in 2013, 2015, and 2016. The nonnative invasive yellow-flowered lotus (Lotus corniculatus) was added in 2015 and 2016. The NPS did not conduct quantitative vegetation monitoring at the site in 2014 due to staffing limitations. Salix lasiolepis, a woody native species, was planted but was not a priority species for monitoring because of its abundance in the surrounding area, and it was not included in the analysis.
NPS staff and partners estimated the abundances of these species within the excavated portion of the project area (Fig. 2) using square nested frequency quadrat sizes $0.1 \times 0.1 \mathrm{~m}$, $0.25 \times 0.25 \mathrm{~m}, 0.5 \times 0.5 \mathrm{~m}$, and $1 \times 1 \mathrm{~m}$ (see Elzinga et al. 1998 for a detailed description of monitoring vegetation abundance in frequency quadrats). Data were analyzed using Pearson's chi-square test for binomial data sets. Results presented in Tables 1 and 2 consist of comparisons of percent frequency for all target species in each quadrat size between 2012 and 2016 . In addition, NPS staff estimated percent frequency of all target species for each monitoring year in $1 \times 1$-m quadrats (Table 2).

Observers established a 195-m baseline parallel to the road along the southwest margin of the restoration site. For each sampling year, observers established transects approximately perpendicular to the baseline at regular, random intervals (systematically placed every fifth meter along the baseline with a random start; i.e., each year observers rerandomized the transect locations). Transects ran across the entire restoration area and ended where they encountered surface water or left the restoration area. Observers established sampling points along transects at 5-m paced intervals (systematically placed, with a random start for each transect). They placed the nested frequency quadrat at each interval, with the corner of the quadrat at the paced-to point and the body of the quadrat falling to the northeast of the point. Observers noted on the data sheet whether each target species was rooted in each of the 4 sizes of quadrat.

The monitoring design used multiple quadrat sizes to track both low-abundance and common species in the project area (Elzinga et al. 1998). The team can track changes in the low-abundance plants by examining data from the larger quadrats, as these plants will show up infrequently (if at all) in the smaller quadrats. Conversely, common species will appear in close to $100 \%$ of the larger quadrats, so in order to track increases in the abundance of common species the team can evaluate data from the smaller quadrat sizes.

\section{RESULTS}

Of the 8 herbaceous species planted, abundance of 3 species increased significantly between 2012 and 2016, 2 species declined in 


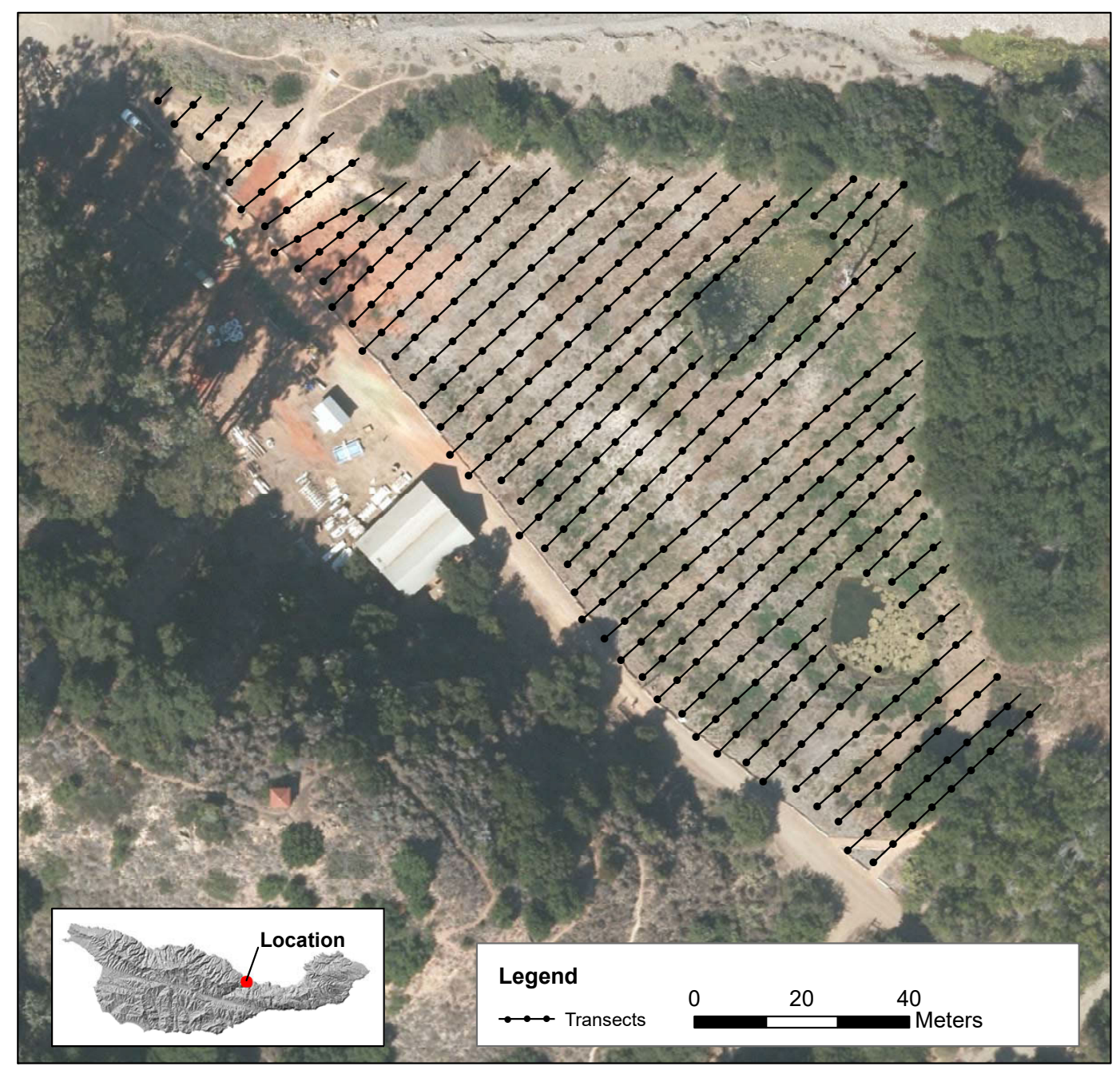

Fig. 2. Vegetation monitoring quadrat locations, Santa Cruz Island.

abundance, and the remaining 3 planted species showed no significant change in abundance (Tables 1, 2). Baccharis douglasii increased from $1.30 \%$ to $9.02 \%$ frequency $(P$ $<0.0001)$, D. spicata increased from $15.2 \%$ to $35.5 \%$ frequency $(P<0.0001)$, and $J$. mexicanus increased from $15.2 \%$ to $32.2 \%$ frequency $(P<0.0001)$. Juncus patens declined from $29.6 \%$ to $8.47 \%$ frequency $(P<0.0001)$ and J. xiphioides declined from $1.30 \%$ to $0.00 \%(P=0.0028)$. The monitoring picked up no significant changes in the abundances of S. californicus, S. maritimus, and S. pungens.

The NPS monitored 2 nonnative invasive species, C. dactylon and L. corniculatus, to inform management action. Cynodon dactylon increased in abundance from $0.70 \%$ to $33.1 \%$ frequency in $1 \times 1-\mathrm{m}$ quadrats between 2013 and 2016. Abundance of L. corniculatus was $35.6 \%$ frequency in $1 \times 1-\mathrm{m}$ quadrats in 2015 , which was the first year this species was monitored, but it declined to $17.2 \%$ frequency in 2016 following a control effort.

\section{Discussion}

Precipitation on Santa Cruz Island during the 5 years after completion of the Prisoners Harbor restoration in late 2011 was consistently well below the long-term annual average of 19.5 inches $(49.5 \mathrm{~cm})$. Data from the Western Regional Climate Center weather station 
TABLE 1. Percent frequency of target species by quadrat size in 2012 and 2016.

\begin{tabular}{|c|c|c|c|c|c|c|c|c|}
\hline \multirow[b]{3}{*}{ Target species } & \multicolumn{8}{|c|}{ Quadrat size } \\
\hline & \multicolumn{2}{|c|}{$0.1 \times 0.1 \mathrm{~m}$} & \multicolumn{2}{|c|}{$0.25 \times 0.25 \mathrm{~m}$} & \multicolumn{2}{|c|}{$0.5 \times 0.5 \mathrm{~m}$} & \multicolumn{2}{|c|}{$1 \times 1 \mathrm{~m}$} \\
\hline & 2012 & 2016 & 2012 & 2016 & 2012 & 2016 & 2012 & 2016 \\
\hline Baccharis douglasii & - & 1.4 & - & 5.7 & 0.8 & 7.7 & 1.3 & 9.0 \\
\hline Distichlis spicata & 3.7 & 12.3 & 7.6 & 27.3 & 10.5 & 31.7 & 15.2 & 35.5 \\
\hline Juncus mexicanus & 1.6 & 9.3 & 2.9 & 23.0 & 5.8 & 27.3 & 15.2 & 32.2 \\
\hline Juncus patens & 2.1 & 1.1 & 9.2 & 4.4 & 14.4 & 6.3 & 29.6 & 8.5 \\
\hline Juncus xiphioides & - & - & - & - & - & - & 1.3 & - \\
\hline Salix lasiolepis & 5.8 & 1.6 & 8.6 & 7.1 & 14.1 & 10.9 & 18.8 & 14.2 \\
\hline Schoenoplectus californicus & 0.5 & 2.2 & 1.8 & 5.2 & 4.5 & 6.6 & 8.4 & 8.2 \\
\hline Schoenoplectus maritimus & 0.3 & - & 0.3 & 0.3 & 0.5 & 0.5 & 0.8 & 0.5 \\
\hline Schoenoplectus pungens & 0.8 & 1.6 & 2.4 & 5.7 & 5.8 & 7.4 & 9.7 & 9.0 \\
\hline
\end{tabular}

TABLE 2. Percent frequency of target species in $1 \times 1$-m plots in 2012, 2013, 2015, and 2016.

\begin{tabular}{|c|c|c|c|c|c|}
\hline \multirow[b]{2}{*}{ Target species } & \multicolumn{4}{|c|}{ Year } & \multirow{2}{*}{$\begin{array}{c}P \text { value for } \\
\text { change } 2012-2016\end{array}$} \\
\hline & 2012 & 2013 & 2015 & 2016 & \\
\hline Baccharis douglasii & 1.3 & 4.4 & 11.7 & 9.0 & $1.6 \times 10^{-6 *}$ \\
\hline Distichlis spicata & 15.2 & 19.5 & 30.4 & 35.5 & $1.5 \times 10^{-10 *}$ \\
\hline Juncus mexicanus & 15.2 & 18.8 & 29.0 & 32.2 & $3.9 \times 10^{-8 *}$ \\
\hline Juncus patens & 29.6 & 20.2 & 11.7 & 8.5 & $2.5 \times 10^{-13 * *}$ \\
\hline Juncus xiphioides & 1.3 & - & 0.3 & - & $0.028 * *$ \\
\hline Schoenoplectus californicus & 8.4 & 8.9 & 10.0 & 8.2 & 0.929 \\
\hline Schoenoplectus maritimus & 0.8 & 0.2 & 1.1 & 0.5 & 0.689 \\
\hline Schoenoplectus pungens & 9.7 & 7.4 & 12.3 & 9.0 & 0.753 \\
\hline
\end{tabular}

*Significant increase in frequency

**Significant decrease in frequency

TABLE 3. Annual precipitation from 2011 to 2016 recorded at the Santa Cruz Island weather station (Main Ranch, Central Valley)

\begin{tabular}{lcc}
\hline Yeara & $\begin{array}{c}\text { Total precipitation } \\
\text { (inches) }\end{array}$ & $\begin{array}{c}\text { Percentage of long-term (1904-2016) } \\
\text { average annual precipitation (19.5 inches) }\end{array}$ \\
\hline $2011 / 12$ & 13.22 & $68 \%$ \\
$2012 / 13$ & 9.53 & $49 \%$ \\
$2013 / 14$ & 7.74 & $40 \%$ \\
$2014 / 15$ & 10.86 & $56 \%$ \\
$2015 / 16$ & 9.47 & $49 \%$ \\
5 -year average & 10.16 & $52 \%$ \\
\hline
\end{tabular}

aEach entry in this column represents July of the first year through June of the following year.

located in the island's Central Valley (WRCC 2017; Table 3) indicate that precipitation averaged only 10.2 inches $(25.9 \mathrm{~cm})$ per year during this time period, or $52 \%$ of the longterm average. Only 2 of the 5 years in this period exceeded $50 \%$ of average annual precipitation.

By February 2012, two months after the NPS and its contractors completed planting, the U.S. Drought Monitor (National Drought Mitigation Center 2017) classified Santa Cruz Island as being in an "Abnormally Dry" condition. As below-normal precipitation trends continued, a "Moderate Drought" began in
April 2013 and conditions worsened to "Severe Drought” in summer 2013. By February 2014, Santa Cruz Island reached the "Extreme Drought" classification, and by July 2014 the U.S. Drought Monitor declared an "Exceptional Drought" for the island (Tercek et al. 2014). This drought condition persisted for the next 2.5 years until more than 9 inches $(22.9 \mathrm{~cm})$ of rain fell in January 2017.

Monitoring efforts did not detect any J. xiphioides, a sparsely planted species, in 2013 or 2016. At the time of planting, many individual plants were infected with rust disease. Likely due to the stresses of disease and 

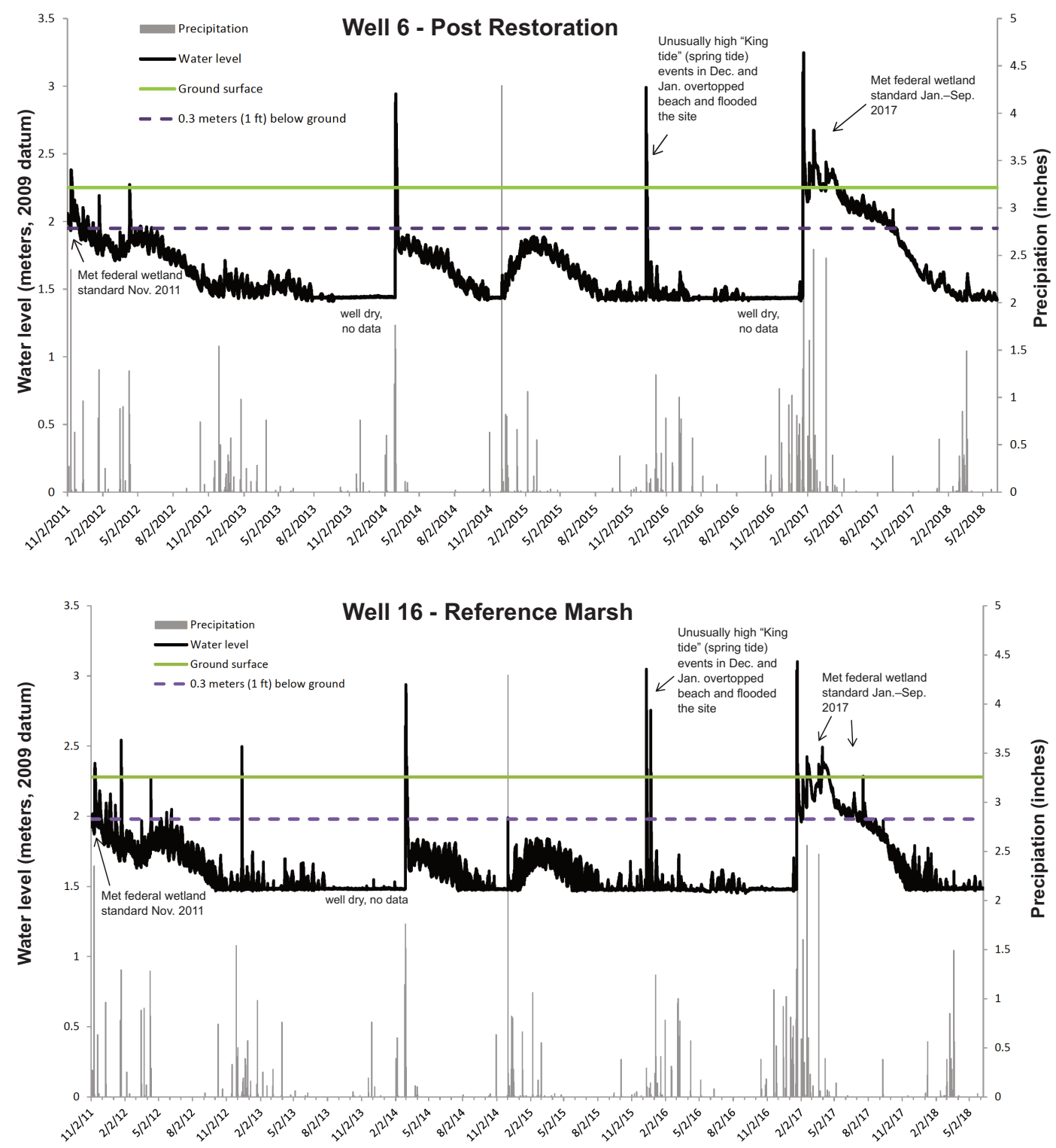

Fig. 3. Postrestoration hydrographs for well 6 (restored marsh) and well 16 (reference marsh used to guide restoration design). Water levels in the restored and reference marshes are very similar in their responses to precipitation and in their elevations above or below the ground surface. Both sites met the federal wetland hydrology standard (water table within $0.3 \mathrm{~m}$ of the ground surface for 14 or more consecutive days) in November-December 2011 and in JanuarySeptember 2017 but failed to meet the standard during the extended drought from 2012 to 2016.

drought, this species did not establish. Another sparsely planted species, S. maritimus, naturally recruited in a narrow band adjacent to S. californicus plantings. Observers recorded plants there through 2016, but these plants did not survive. On the other hand, observers noted an abundance of S. californicus in areas with appropriate groundwater elevation.
NPS staff planted B. douglasii only sparsely in 2011, but by 2016 its abundance had increased significantly. NPS staff observed it in just over $1 \%$ of the $1 \times 1-m$ quadrats in 2012 and in about $9 \%$ of these quadrats in 2016. Most of this increase occurred on the north side of the excavated wetland due to natural recruitment. 
Although NPS staff planted J. patens widely in 2011, a number of factors, including extreme drought and resulting low water table, likely contributed to its significant decline in abundance each year. It will likely remain a subdominant species in the restored wetland.

Vegetation monitoring from 2013 to 2016 showed that growth of C. dactylon and L. corniculatus outstripped growth of 6 of the 8 native species planted in 2011. These results highlight the importance of quickly and aggressively controlling invasive species early during restoration to give native species an opportunity to establish without competition, especially in drought conditions. Park staff chemically and manually removed $L$. corniculatus with good results in 2015 and 2016 (abundance declined from 35.6\% frequency in 2015 to $17.2 \%$ frequency in 2016). However, in 2017, staff observed an explosion of L. corniculatus across the wetland. The unexpected reappearance of $L$. corniculatus underscored the need for continued aggressive weed management for at least 5-10 years following restoration.

Figure 3 shows a representative hydrograph for the restored marsh area (well 6) and for the adjacent reference wetland site that was used to guide marsh restoration design (well 16). These hydrographs show that water levels were well below the ground surface for both sites during the extreme drought from winter $2011 / 12$ to early winter $2016 / 17$. The minimum federal standard for determining whether a site has wetland hydrology is that it is inundated (flooded or ponded) or the water table is $\leq 0.3 \mathrm{~m}$ below the soil surface for at least 14 consecutive days during the growing season at a minimum frequency of 5 years in $10(\geq 50 \%$ probability; U.S. Army Corps of Engineers 2005). As a result of the drought, the restored marsh met the water level duration criterion only twice during the study period: once in late 2011 and again in January-September 2017. However, hydrologic conditions track very closely to conditions at the adjacent, undisturbed reference wetland site (well 16 in Fig. 3), which was also affected by the extreme drought.

A large swell and high tide event during December 2015 caused a brief (less than 7-d duration) seawater inundation of the entire wetland area. Based on repeated salinity measurements during the period of 12 December 2015 to 27 January 2017 in observation wells
6 and 7 and in both ponds, ground and surface water at the site remained brackish until winter rains arrived in November 2016. There is historical evidence of occasional seawater influence on the wetland. Stehman Forney of the U.S. Coast Survey described the lagoon and water well at Prisoners Harbor while mapping the island in 1875 , stating that "there is a well of fresh water, but it is not so good as that in the pond, when not impregnated with salt." (Livingston 2016). With the exception of willows, species planted in the wetland are tolerant of and did not appear to be harmed by the saltwater inundation and prolonged brackish conditions.

Expansion of wetland species, even during a historic drought and atypical seawater intrusion, suggests that this evidence-based approach to restoration design will result in functional coastal wetland habitat as more typical precipitation levels return. However, we emphasize the need for aggressive control of nonnative plants until native plant cover is well established.

\section{ACKNOWLEDGMENTS}

We thank Kevin Noon, Tim Jones, Clark Cowan, James Roberts, Rocky Rudolph, Rosalie Schubert, Peter Larramendy, Jackson Van Fleet Brown, and other park staff, scientists, and volunteers who supported this project.

\section{Literature Cited}

ArNold, J., EDITOR. 2001. The origins of a Pacific Coast chiefdom, the Chumash of the Channel Islands. University of Utah Press, Salt Lake City, UT.

Elzinga, C.L., D.W. Salzer, and J.W. Willoughby. 1998. Measuring and monitoring plant populations. BLM Technical Reference 1730-1, U.S. Department of the Interior, Bureau of Land Management, Denver, CO. https://digitalcommons.unl.edu/usblmpub/17

GLassow, M. 1980. Recent developments in the archaeology of the Channel Islands. Pages 79-99 in D. Power, editor, The California islands: proceedings of a multidisciplinary symposium. Santa Barbara Museum of Natural History, Santa Barbara, CA.

Livingston, D.S. 2016. Island legacies: a history of the islands within Channel Islands National Park, San Miguel Island, Santa Rosa Island, Santa Cruz Island, Anacapa Island, Santa Barbara Island. U.S. Department of the Interior, National Park Service, Channel Islands National Park, Ventura, CA.

National Drought Mitigation Center. 2017. United States drought monitor. University of NebraskaLincoln, Lincoln, NE. https://droughtmonitor.unl.edu

Power, P.J., J. Wagner, M. Martin, and M. Denn. 2014. Restoration of a coastal wetland at Prisoners Harbor, 
Santa Cruz Island, Channel Islands National Park, California. Monographs of the Western North American Naturalist 7:442-454.

Schoenherr, A.A., C.R. Feldmeth, and M.J. Emerson. 1999. Natural history of the Islands of California. University of California Press, Berkeley, CA.

Tercek, M.T., A. Klein, and P. Power. 2014. Mediterranean Coast Network Climate of 2013 annual report: Channel Islands National Park. Natural Resource Data Series NPS/MEDN/NRDS—2014/732, National Park Service, Fort Collins, CO.

U.S. ARMy CoRps of EngineErs. 2005. Technical standard for water-table monitoring of potential wetland sites. ERDC TN-WRAP-05-02, U.S. Army Engineer Research and Development Center, Vicksburg, MS

[WRCC] Western Regional Climate Center. 2017. RAWS weather station, Santa Cruz Island, California. https://www.raws.dri.edu/cgi-bin/rawMAIN.pl?ca CSCI

Received 15 March 2017 Revised 26 December 2017 Accepted 14 March 2018 Published online 20 December 2018 